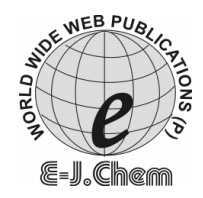

ISSN: 0973-4945; CODEN ECJHAO

\title{
Synthesis Characterization and Biological Investigations on Metal Complexes of 2-[(8-Hydroxy- 1-quinolin-5-yl) methyl]-1H-isoindole-1, 3 (2H) dione
}

\author{
M. R. SOLANKI*, G. D. ACHARYA and M. V. HATHI \\ Chemistry Department (P. G. Center), \\ R. R. Mehta Science \& C. L. Parikh Commerce College, \\ Palanpur-385001, N. Gujarat, India. \\ gdacharya@yahoo.in
}

Received 3 January 2009; Accepted 5 March 2009

\begin{abstract}
The more significant biologically active $\mathrm{Cu}(\mathrm{II}), \mathrm{Ni}(\mathrm{II}), \mathrm{Co}(\mathrm{II})$ and $\mathrm{Mn}$ (II) complex were synthesized by using $N$-hydroxymethyl phthalimide and 8-hydroxy quinoline as ligand. Synthesized complexes were characterized by elemental analysis, conductance, magnetic susceptibility measurements, IR and reflectance spectral studies. Coordination of the ligand atom to the metal ion was deduced by IR and reflecting spectral data. Structures of the complexes were confirmed by magnetic studies. All the complexes have been screened for antibacterial and antifungal.
\end{abstract}

Keywords: Hydroxy methyl phthalimide, Antibacterial, Antifungal, Isoindole.

\section{Introduction}

Survey of literature reveals that, the importance of $N$-aryl hydroxy methyl phthalimide derivatives as biologically, pharmacologically, hypoglycemic active and industrially important molecules. The complexes obtained from the ligands having acetyl, benzyl, hydroxy, ketone as functional groups have been investigated exhaustively.

Receiving impetus from the above observation and in continuation of our research programmed on complexes of HMP derivatives. In this paper, we report the synthesis of synthesis of 2-[(8-hydroxy-1-quinolin-5-yl) methyl]-1H-isoindole-1, 3 (2H)-dione and its complexes with $\mathrm{Cu}(\mathrm{II}), \mathrm{Ni}(\mathrm{II}), \mathrm{Mn}$ (II) and $\mathrm{Zn}$ (II) and also biological activities of these complexes. Hydroxy methyl phthalimide a potential donor ligand with four coordination sites is having structure (Scheme 1). 


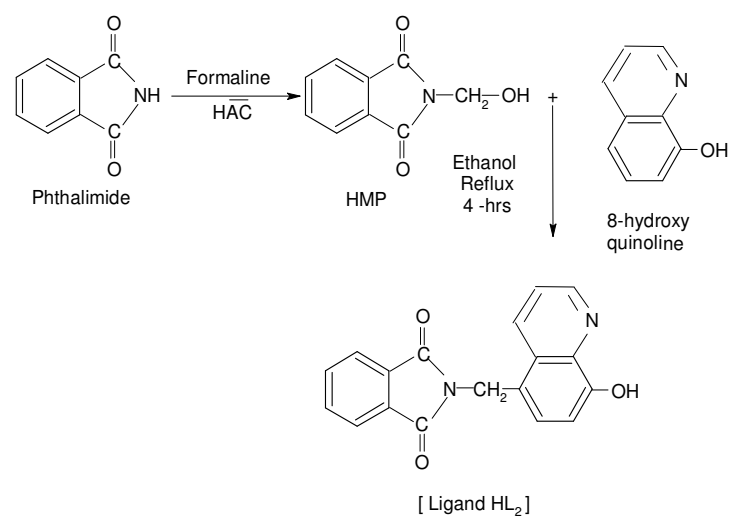

\section{Experimental}

Scheme 1

Phthalimide and the ligands used for synthesis of novel phthalimide derivatives were obtained from local market. The metal salts and other chemicals used were of laboratory grade. Solvent were dried and distilled before used. The following metal salts were used to prepare complexes. Copper acetate $\left[\mathrm{Cu}(\mathrm{COO})_{2}\right]$, cobalt acetate $\left[\mathrm{Co}(\mathrm{COO})_{2}\right]$, nickel acetate, manganese acetate $\left[\mathrm{Mn}(\mathrm{COO})_{2}\right]$ for the preparation of ligand 2-[(8-hydroxy-1-quinolin-5-yl) methyl]-1 $H$ - isoindole-1, $3(2 H)$-dione.

To a solution of (0.04 mole) 8-hydroxy quinoline in ethanol and solution of (0.04 mole) hydroxy methyl phthalimide (HMP) in $50 \mathrm{~mL}$ ethanol, 5 drops of con. $\mathrm{HCl}$ was added. The two resultant solutions were mixed with vigorous stirring at room temperature. The resultant mixture was refluxed for about 4 hours and cooled. The precipitates were separated, dried and crystallized with acetone. The yield was about $75 \%$ and melting point was $142{ }^{\circ} \mathrm{C}$ (Uncorrected). The ligands $\mathrm{HL}_{2}$ described above have been taken. $\mathrm{The}^{\mathrm{C}} \mathrm{u}^{2+}, \mathrm{Mn}^{2+}, \mathrm{Co}^{2+}$ and $\mathrm{Ni}^{2+}$ metal ion complexes of $\mathrm{HL}_{2}$ were prepared. The procedure is given below.

To the solution of metal acetate $(0.01 \mathrm{M})$ in water $(25 \mathrm{~mL})$ and solution of ligand $\mathrm{HL}_{2}$ $(0.02 \mathrm{M})$ in formic acid: water mixture $(50: 50 \mathrm{v} / \mathrm{v})(100 \mathrm{~mL})$ was added gradually with vigorous stirring at room temperature. The resultant mixture was refluxed for about $4 \mathrm{~h}$. The solid complexes was separated by concentrating the resultant solution and adding ethanol:water mixture (70:30 ratio).The precipitates were filtered and washed several times with ethanol : water (70:30 ratio). The precipitates were dried at about $60{ }^{\circ} \mathrm{C}$. Yield was about 65 to $75 \%$. The details of the elemental analysis, molar conductance of the complexes are given in Table 1 . Ligand $\mathrm{HL}_{2}$ and its synthesized complexes were insoluble in water, slightly soluble in methanol, ether, chloroform, benzene and other organic solvents. They were soluble in DMF and acetonitrile. All the samples were measured by elemental analyzer Thermo Finiggan 1101 Flash EA.

The molar conductance of the complexes was measured using Elico CM-28. Magnetic suscepetibility measurements were made on a Gouy balance at room temperature using conductivity water and mercury tetrathiocynatocobaltate(II) $\left[\mathrm{HgCo}(\mathrm{CNS})_{4}\right]$ as calibrant. The reflectance spectra of the metal chelates in the visible region were recorded against $\mathrm{MgO}$ on Beckman-Dk-2A spectrophotmter. The IR spectra of metal complexes were recorded in $\mathrm{KBr}$ in the range of 4000 $400 \mathrm{~cm}^{-1}$ Unicom FTIR (research spectrophotometer series) and in the range of $4000-200 \mathrm{~cm}^{-1}$ were recorded on Perkin Elmer -577IR spectrophotometer. The antimicrobial activities of the synthesized metal complexes were carried out by the cup-plate method. In vitro antimicrobial activity was carried out against $24 \mathrm{~h}$ old cultures of two bacteria, namely Staphylococcus aureus and E. coli and $48 \mathrm{~h}$ old culture of two fungi, namely Nigrospora sp. and Rhizopus nigricum. 
Table 1. Physical and analytical data of ligand and their metal complexes.

\begin{tabular}{|c|c|c|c|c|c|c|c|c|c|c|c|}
\hline \multirow{3}{*}{ Metal Complex } & \multirow{3}{*}{$\begin{array}{l}\text { Yield } \\
\%\end{array}$} & \multirow{3}{*}{$\begin{array}{l}\text { M.Wt } \\
\text { g/mole }\end{array}$} & \multicolumn{6}{|c|}{ Elemental analysis } & \multirow{2}{*}{\multicolumn{2}{|c|}{$\begin{array}{c}\text { Metal } \\
\%\end{array}$}} & \multirow{3}{*}{$\begin{array}{l}\text { Condu- } \\
\text { ctivity, } \\
\text { Mohs. } \\
\mathrm{cm}^{2}\end{array}$} \\
\hline & & & \multicolumn{2}{|c|}{$\mathrm{C} \%$} & \multicolumn{2}{|c|}{$\mathrm{H} \%$} & \multicolumn{2}{|c|}{$\mathrm{N} \%$} & & & \\
\hline & & & Calc. & Found & Calc. & Found & Calc. & Found & Calcu. & Found & \\
\hline (HMT) $\mathrm{C}_{18} \mathrm{H}_{12} \mathrm{~N}_{2} \mathrm{O}_{3}$ & 75 & 304 & 71.05 & 67.1 & 3.94 & 3.8 & 9.21 & 9.1 & - & - & - \\
\hline$\left(\mathrm{HL}_{2}\right)_{2} \mathrm{Cu}^{2+} 2 \mathrm{H}_{2} \mathrm{O}$ & 73 & 703.5 & 61.4 & 61.0 & 3.69 & 3.6 & 7.95 & 7.9 & 9.03 & 9.0 & 7.7 \\
\hline$\left(\mathrm{HL}_{2}\right)_{2} \mathrm{Co}^{2+} 2 \mathrm{H}_{2} \mathrm{O}$ & 71 & 698.9 & 61.8 & 61.2 & 3.71 & 3.7 & 8.01 & 8.0 & 8.43 & 8.4 & 9.3 \\
\hline$\left(\mathrm{HL}_{2}\right)_{2} \mathrm{Ni}^{2+} 2 \mathrm{H}_{2} \mathrm{O}$ & 70 & 698.6 & 61.82 & 61.4 & 3.71 & 3.7 & 8.01 & 8.0 & 8.40 & 8.2 & 8.0 \\
\hline$\left(\mathrm{HL}_{2}\right)_{2} \mathrm{Mn}^{2+} 2 \mathrm{H}_{2} \mathrm{O}$ & 70 & 694.9 & 62.16 & 62.0 & 3.74 & 3.7 & 8.05 & 8.0 & 7.9 & 7.7 & 10.7 \\
\hline
\end{tabular}

Table 2. Experimental data of magnetic moment for metal chelates of $\mathrm{HL}_{2}$

\begin{tabular}{cccccc}
\hline $\begin{array}{c}\text { Metal } \\
\text { Chelates }\end{array}$ & $\begin{array}{c}\chi_{\mathrm{g}} \times 10^{-6} \\
\text { cgs }\end{array}$ & $\begin{array}{c}\chi_{\mathrm{m}} \times 10^{-6} \\
\text { cgs }\end{array}$ & $\begin{array}{c}\text { Magnetic } \\
\text { moment } \\
\mu_{\text {off }, \mathrm{BM}}\end{array}$ & $\begin{array}{c}\mu_{\text {off= } \mathrm{n}(\mathrm{n}+2)} \\
\mathrm{BM} \\
\text { Obs. }\end{array}$ & $\begin{array}{c}\mu_{\text {off }}, \mathrm{BM} \\
\text { Expected }\end{array}$ \\
\hline$\left(\mathrm{HL}_{2}\right)_{2} \mathrm{Mn}^{2+}$ & 19.46 & 13529 & 5.73 & 5.91 & $5.2-6.0$ \\
$\left(\mathrm{HL}_{2}\right)_{2} \mathrm{Co}^{2+}$ & 12.52 & 8757 & 4.61 & 3.87 & $4.4-5.2$ \\
$\left(\mathrm{HL}_{2}\right)_{2} \mathrm{Ni}^{2+}$ & 5.55 & 3883 & 3.07 & 2.82 & $2.9-3.4$ \\
$\left(\mathrm{HL}_{2}\right)_{2} \mathrm{Cu}^{2+}$ & 2.22 & 1566 & 1.95 & 1.73 & $1.7-2.2$ \\
\hline
\end{tabular}




\section{Results and Discussion}

The data of electrical conductivity of all the complexes in acetone indicates that they are less polarising in $\mathrm{DMF}$. The magnetic moment of $\mathrm{CO}, \mathrm{Ni}$, and $\mathrm{Cu}(\mathrm{II})$ complexes were calculated from the corrected magnetic susceptibilities ( $c f$. Table 2). The magnetic moment value of 2.82 B.M. was observed for complex of $\mathrm{Ni}$ (II) witch is well within the range of 2.9-3.4 B.M. expected for octahedral complexes. The $\mathrm{Cu}(\mathrm{II})$ complex exhibited magnetic moment of the order of 1.95 B.M. which's agrees well with the spin only value, suggesting octahedral structure. The Mn(II) complex exhibited magnetic moment of the order of 5.9 B.M. showed highly paramagnetic property

The electronic spectrum of Co(II) complexes exhibited three bands around, 23809,19607 and $8196 \mathrm{~cm}^{-1}$ which are assigned to $\left(\mathrm{V}_{1}\right){ }^{4} \mathrm{~T}_{1 \mathrm{~g}}(\mathrm{~F}) \rightarrow{ }^{4} \mathrm{~T}_{2 \mathrm{~g}}(\mathrm{~F}),\left(\mathrm{V}_{2}\right){ }^{4} \mathrm{~T}_{1 \mathrm{~g}}(\mathrm{~F}) \rightarrow{ }^{4} \mathrm{~A}_{2 \mathrm{~g}}$ and $\left(\mathrm{V}_{3}\right)$ ${ }^{4} \mathrm{~T}_{1 \mathrm{~g}}(\mathrm{~F}) \rightarrow{ }^{4} \mathrm{~T}_{2 \mathrm{~g}}(\mathrm{P})$ respectively in an octahedral environment field (Table 3 ). The electronic spectrum of $\mathrm{Ni}$ (II) complex also showed three bands. in electronic spectra of $\mathrm{Cu}^{+2}$ metal chelate of each of the ligands may be assigned to ${ }^{2} \mathrm{~B}_{1 \mathrm{~g}} \rightarrow{ }^{2} \mathrm{~A}_{1 \mathrm{~g}}$ and charge transfer transition respectively. These results reveal the distorted octahedral geometry for these chelates.

Table 3. Reflectance spectral data of metal complexes of ligand $\mathrm{HL}_{2}$.

\begin{tabular}{cllll}
\hline Metal complex & \multicolumn{2}{l}{ Absorption, $\mathrm{cm}^{-1}$} & \multicolumn{2}{l}{ Transional } \\
\hline$\left(\mathrm{HL}_{2}\right)_{2}-\mathrm{Mn}^{2+}$ & 23785 & ${ }^{6} \mathrm{~A}_{1 \mathrm{~g}}$ & $\rightarrow$ & ${ }^{4} \mathrm{~A}_{1 \mathrm{~g}}(4 \mathrm{EG})$ \\
& 18412 & ${ }^{6} \mathrm{~A}_{1 \mathrm{~g}}$ & $\rightarrow$ & ${ }^{4} \mathrm{~T}_{2 \mathrm{~g}}(4 \mathrm{G})$ \\
& 16724 & ${ }^{6} \mathrm{~A}_{1 \mathrm{~g}}$ & $\rightarrow$ & ${ }^{4} \mathrm{~T}_{1 \mathrm{~g}}(4 \mathrm{G})$ \\
$\left(\mathrm{HL}_{2}\right)_{2}-\mathrm{Co}^{2+}$ & 23809 & ${ }^{4} \mathrm{~T}_{\mathrm{gg}}(\mathrm{F})$ & $\rightarrow$ & ${ }^{4} \mathrm{~T}_{2 \mathrm{~g}}(\mathrm{~F})$ \\
& 19607 & ${ }^{4} \mathrm{~T}_{1 \mathrm{~g}}(\mathrm{~F})$ & $\rightarrow$ & ${ }^{4} \mathrm{~A}_{2 \mathrm{~g}}$ \\
& 08196 & ${ }^{4} \mathrm{~T}_{1 \mathrm{~g}}(\mathrm{~F})$ & $\rightarrow$ & ${ }^{4} \mathrm{~T}_{2 \mathrm{~g}}(\mathrm{P})$ \\
$\left(\mathrm{HL}_{2}\right)_{2}-\mathrm{Ni}^{2+}$ & 22106 & ${ }^{3} \mathrm{~A}_{2 \mathrm{~g}}$ & $\rightarrow$ & ${ }^{3} \mathrm{~T}_{1 \mathrm{~g}}(\mathrm{P})$ \\
& 15472 & ${ }^{3} \mathrm{~A}_{2 \mathrm{~g}}$ & $\rightarrow$ & ${ }^{3} \mathrm{~T}_{1 \mathrm{~g}}(\mathrm{~F})$ \\
$\left(\mathrm{HL}_{2}\right)_{2}-\mathrm{Cu}^{2+}$ & 24165 & $\mathrm{Charg}^{2} \rightarrow$ & ${ }^{2}$ Transfer \\
& 14970 & ${ }^{2} \mathrm{~B}_{1 \mathrm{~g}}$ & $\rightarrow$ & ${ }^{2} \mathrm{~A}_{1 \mathrm{~g}}$ \\
\hline
\end{tabular}

The reflectance spectra of the metal chelates in the visible region were recorded against $\mathrm{MgO}$ on Beckman-DK-2A spectrophotometer (Figure 1). The assignment of significant bands present in the reflectance spectra of each of the metal chelates are furnished in Table 3.

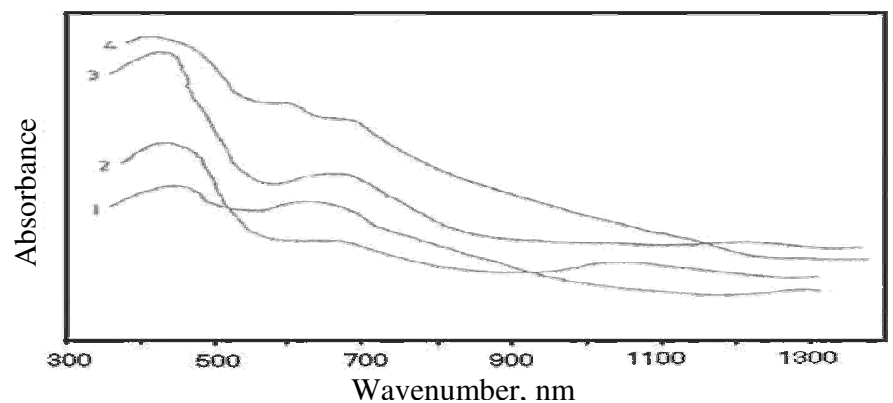

Figure 1. Reflectance spectra of $\mathrm{HL}_{2}$ metal complexes (1) $\mathrm{HL}_{2} \mathrm{Cu}$ (2) $\mathrm{HL}_{2} \mathrm{Ni}$ (3) $\mathrm{HL}_{2} \mathrm{Co}$ (4) $\mathrm{HL}_{2} \mathrm{Mn}$ (The band value in $\mathrm{nm}$ is converted into $\mathrm{cm}^{-1}$ and discussed in text).

The only observable difference in the IR spectra of metal chelates and corresponding ligands has been the disappearance of the $\mathrm{C}=\mathrm{O}$ stretching vibration in ligands at $1730 \mathrm{~cm}^{-1}$ on complex formation. A new band at $1095 \mathrm{~cm}^{-1}$ had appeared in the spectra of metal chelates. 
Table 4. Infrared frequencies of $\mathrm{HL}_{2}$ and their metal complexes.

\begin{tabular}{|c|c|c|c|c|c|}
\hline \multicolumn{6}{|c|}{ Frequency $\mathrm{cm}^{-1}$} \\
\hline Ligand & Aromatic & Metal ligand & Imides group & $\mathrm{C}=\mathrm{O}$ ketone & $-\mathrm{CH}_{2}$ group, Bridge \\
\hline \multirow{3}{*}{$\mathrm{HL}_{2}$} & $1598 \mathrm{C}=\mathrm{C}$ str. & 3370 str. & 1682 str. & \multirow{3}{*}{1716 str. } & 2922 str. (Asym.) \\
\hline & $1497 \mathrm{C}-\mathrm{H}$ bends. & 1357 bend. & 1578 str. & & 2849 str. (Sym.) \\
\hline & 3028 C-H str. & & 1388 str. & & 1454 bend. \\
\hline \multirow{3}{*}{$\begin{array}{c}\mathrm{HL}_{2^{-}} \\
\mathrm{M}\end{array}$} & $1598 \mathrm{C}=\mathrm{C}$ str. & & 1578 str. & \multirow{3}{*}{1716 str. } & 2922 str. (Asym.) \\
\hline & $1497 \mathrm{C}-\mathrm{H}$ bends. & $580-450$ & 1388 str. & & 2849 str. (Sym.) \\
\hline & & & 1388 str. & & 1454 bend. \\
\hline
\end{tabular}

This may be assigned to $\mathrm{Vc}-\mathrm{O}$ of C-O-Metal bond formation. The important bands are observed at their respective positions. The bands at $1680 \mathrm{~cm}^{-1}$ is due to imides group. The bands at 3030,1600 and $820 \mathrm{~cm}^{-1}$ are mainly from 1,4 disubstituted aromatic ring the bands 2850,2920 and $1450 \mathrm{~cm}^{-1}$ is assigned to $-\mathrm{CH}_{2}$ bridge system.

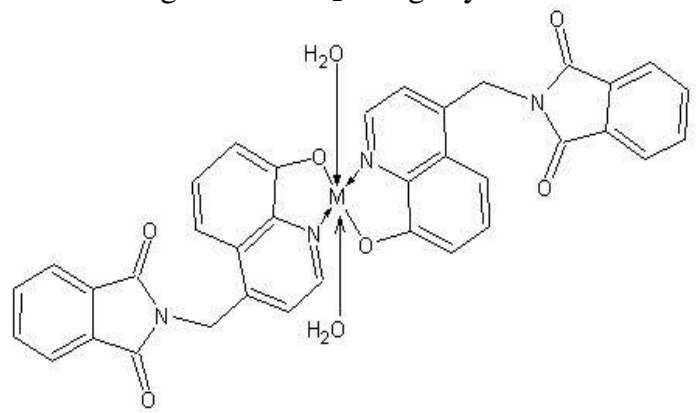

Metal Complexes of HL2

$\mathrm{M}=\mathrm{Cu}(\mathrm{II}), \mathrm{Ni}(\mathrm{II}), \mathrm{Co}(\mathrm{II})$ and $\mathrm{Mn}(\mathrm{II})$

Table 5. Antibacterial and antifungal activity of ligand $\mathrm{HL}_{2}$ and their metal complexes.

\begin{tabular}{ccccc}
\hline & \multicolumn{2}{l}{ Zone of inhibition, in mm } & \multirow{2}{*}{ Zone of inhibition at $1000 \mathrm{ppm}, \%$} \\
\cline { 2 - 5 } Sample & Gram + ve & Gram - ve & Ps. \\
\cline { 2 - 5 } & $\begin{array}{c}\text { Staphylococcus } \\
\text { aureus }\end{array}$ & $\begin{array}{c}\text { Ps. } \\
\text { aeruginosa }\end{array}$ & $\begin{array}{c}\text { Penillium } \\
\text { expansum }\end{array}$ & $\begin{array}{c}\text { Nigrospora } \\
\text { sp. }\end{array}$ \\
\hline $\mathrm{HL}_{2}$ & 17 & 19 & 64 & 65 \\
$\mathrm{HL}_{2}-\mathrm{Cu}^{+2}$ & 20 & 11 & 82 & 87 \\
$\mathrm{HL}_{2} \mathrm{Mn}^{+2}$ & 16 & 14 & 75 & 71 \\
$\mathrm{HL}_{2}-\mathrm{Co}^{+2}$ & 18 & 17 & 75 & 64 \\
$\mathrm{HL}_{2}-\mathrm{Ni}^{+2}$ & 09 & 16 & 72 & 61 \\
\hline
\end{tabular}

The ligands of all the complexes synthesized in the present investigation and the respective metal salts were evaluated for antimicrobial activity. Ligand and all the metal complexes were screened for their antibacterial activity against two bacterial strains viz. Pseudomonas aeruginosa and Staphylococcus aureus (Table 5) these compounds were also evaluated for their antifungal activity against two fungi viz. Penicillium expansum and Nigrospora sp.

\section{Conclusion}

The structures of all the complexes have been assigned based on various spectral and physical parameters. All the complexes possess octahedral geometry. Two water molecules are also involved in complexation. All the complexes exhibited considerable antibacterial 
activity against Staphylococcus aureus and Pseudomonas aeruginosa and anti fungi against Penicillium expansum and Nigrospora sp.

\section{Acknowledgment}

The author is thankful to Exe. Principal Dr. M.V. HATHI, R.R Mehta science college palanpur for providing laboratory facilities and to the director, CICART providing elemental, spectral and antimicrobial activity data.

\section{References}

1 Bhakti, J Sci Ind Res., 1953, 114, 1213.

2 Poddar Z, Ana Chem., 1957, 154, 327.

3 Bhatta D et al., J Indian Chem Soc., 1996, 73, 616.

$4 \quad$ Patra M and Dash B, J Indian Chem Soc., 1978, 55, 587.

5 Sahu S K, Mishra S K, Mahapatra S P, Bhatta D and Panda C S, ibid. J Indian Chem Soc., 2004, 81, 258-260.

6 Nakanishi K, Infrared absorption spectroscopy, Nankando Company Ltd., Tokyo, 1964, 45.

$7 \quad$ Raddy S N and Agarwal B V, Synth React Inorg Chem., 1987, 17, 6-10.

8 Metal Complexes and Metals in Macromolecules: Synthesis, Structure and Properties, Dieter Wohrle, Anatoli D, Pomogailo, John Wiley \& Sons Inc., 2003.

$9 \quad$ Horrowitz E and Perros T P, J Inorg Nucl Chem., 1961, 139, 26.

10 Carlin R L and Van Dryneveldt A J, Megnetic properties of Transition Metal Complexes, Springer, Vorlag, N Y,1997.

11 Sing B and Agarwal G, J Inorg Nucl Chem., 1969, 34, 3449.

12 Rai B K, Kumar K and Srivastav Y P, Asian J Chem., 2005, 17, 1773.

13 Poddar S N, Day K, Haldar J and Nathsarkar S C, J Ind Chem Soc., 1970, 47, 743.

14 Rai B K, Kumar K and Srivastav Y P, Asian J Chem., 2005, 17, 1773.

15 Sujatha G D et al., Indian J Exp Biol., 1975, 13, 286. 


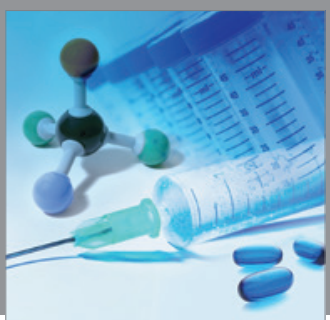

International Journal of

Medicinal Chemistry

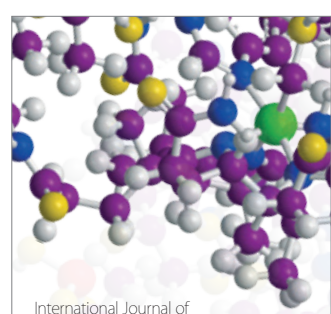

Carbohydrate Chemistry

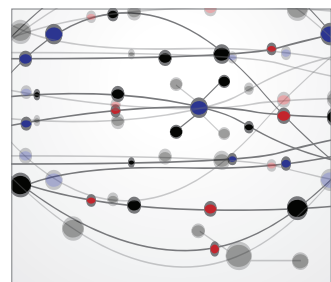

The Scientific World Journal
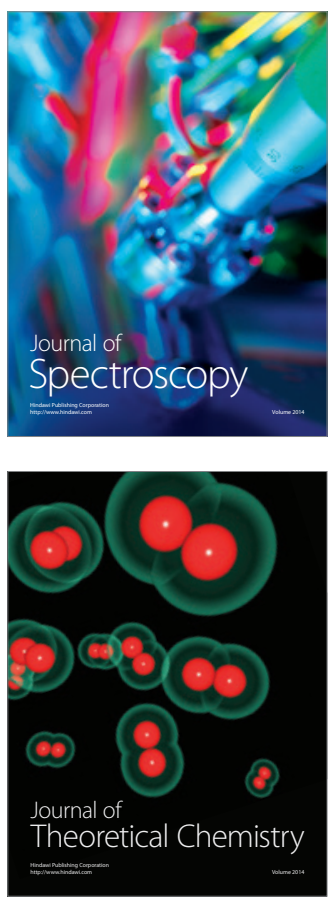
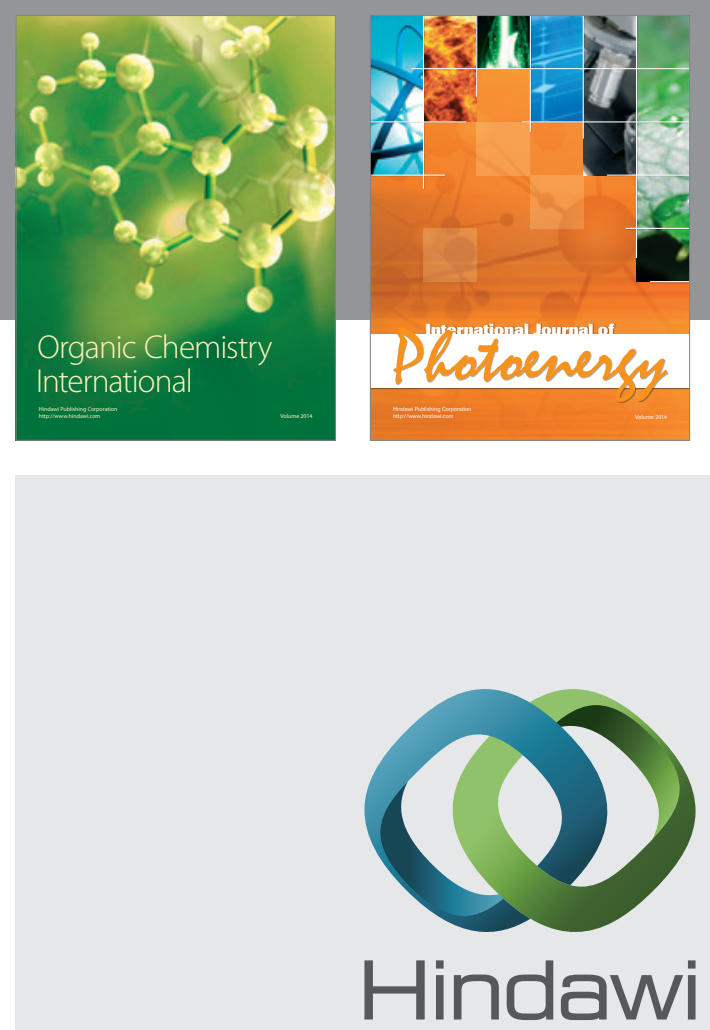

Submit your manuscripts at

http://www.hindawi.com
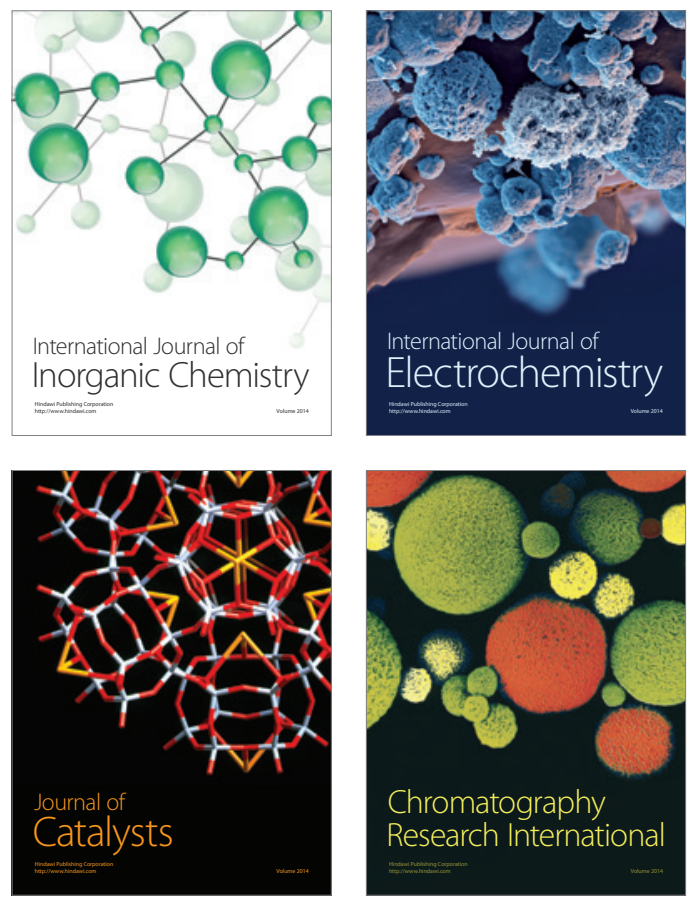
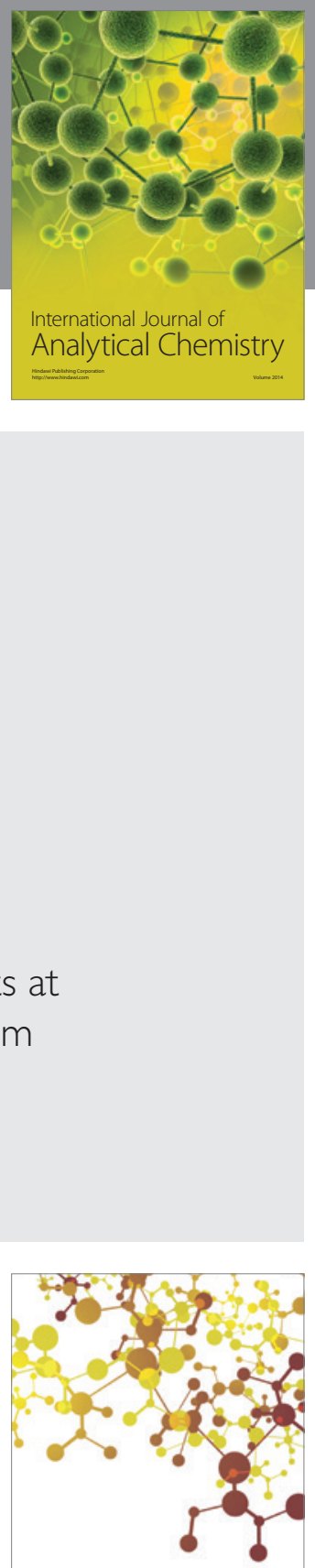

Journal of

Applied Chemistry
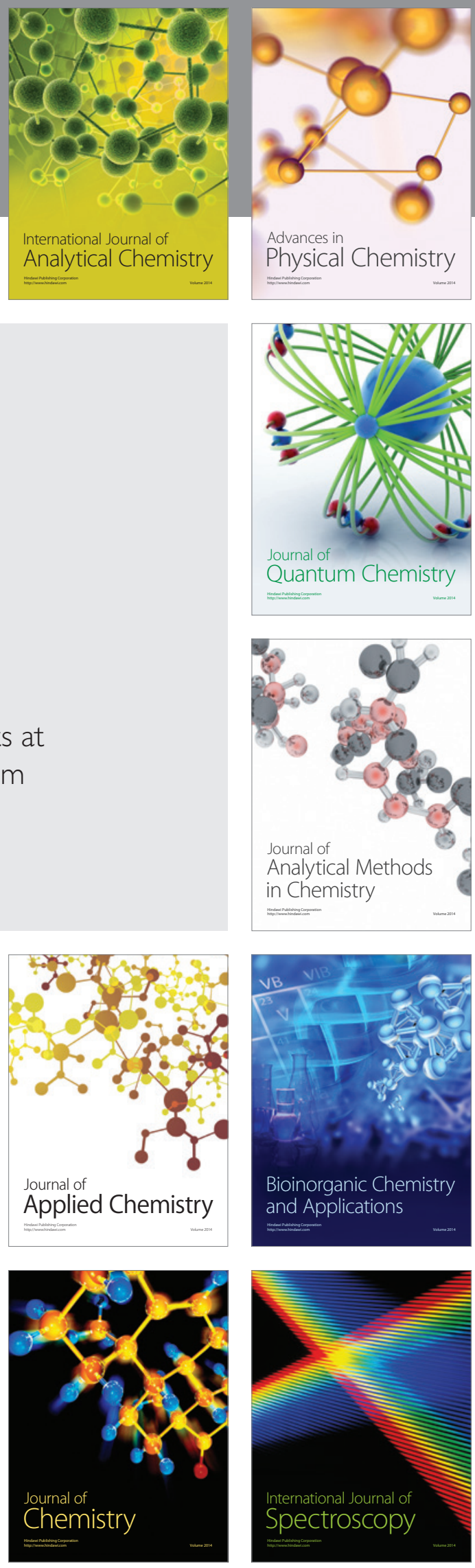